\title{
Effect of stand structure and aspect on the regeneration of banj oak (Quercus leucotrichophora A. Camus) forest along disturbance in Garhwal Himalaya, Uttarakhand, India
}

\author{
Vikaspal Singh ${ }^{1,{ }^{*}}$, Dhanpal Singh Chauhan ${ }^{2}$ and \\ Sabyasachi Dasgupta ${ }^{3}$
}

Singh, V., Chauhan, D.S., Dasgupta, S. 2018. Effect of stand structure and aspect on the regeneration of banj oak (Quercus leucotrichophora A. Camus) forest along disturbance in Garhwal Himalaya, Uttarakhand, India. - Forestry Studies | Metsanduslikud Uurimused 68, 33-39. ISSN 1406-9954. Journal homepage: http:// mi.emu.ee/forestry.studies

\begin{abstract}
A study was conducted in an oak forest, to find out the relationship of stand structure, aspect and regeneration of species. Among all disturbance stands the density of banj oak Quercus leucotrichophora A. Camus individuals was peaked at $40-50 \mathrm{~cm}$ and 50-60 cm diameter at breast height (DBH) classes and low tree density was observed with the increasing DBH classes. North aspect showed higher density for most of girth classes as compared to south facing aspect. Among all the stands, low seedling density was recorded in undisturbed stand at south facing aspect as compared to the moderately and highly disturbed stands. The tree density of Q. leucotrichophora was higher in the undisturbed stand followed by moderately disturbed and highly disturbed stand. But in case of seedling density the higher density were observed at undisturbed and highly disturbed stand in both of the aspects.
\end{abstract}

Key words: disturbance, north aspect, south aspect, tree density, seedling density.

Authors' addresses: ${ }^{1}$ Department of Forestry, Dolphin PG Institute of Biomedical and Natural Sciences, Dehradun, 248007, Uttarakhand, India; ${ }^{2}$ Department of Forestry and Natural Resources, HNBGU, Srinagar Garhwal, Uttarakhand, 246174, India; ${ }^{3}$ Department of Forestry and Biodiversity, Tripura University, Suryamaninagar, Tripura (West), PIN: 799022, India; *e-mail: vikaspals@gmail.com

\section{Introduction}

Lack of sufficient regeneration is a major problem of mountain forests (Krauchi et al., 2000). Most studies on subalpine forest have reported poor recruitment in under stories of undisturbed old-growth forests (Coates, 2002; Mori \& Takeda, 2004). Regeneration through seeds depends on production, dispersal and germination of seeds, and establishment and growth of seedlings. Several factors such as resource availability, pollination success, production of flowers, fruits and leaves, genetic makeup, age and size of plant affect the seed production (Winn \& Werener, 1987).

Stand structure is the physical arrangement and characteristics of the forest and is a highly visible and described component (Stone \& Porter, 1998). Oliver \& Larson (1990) define forest stand structure as the physical and temporal distribution of trees in a stand and include within the distribution of the species, vertical and horizontal spatial patterns, size of trees or tree parts, tree age or combinations. In the context of 
a

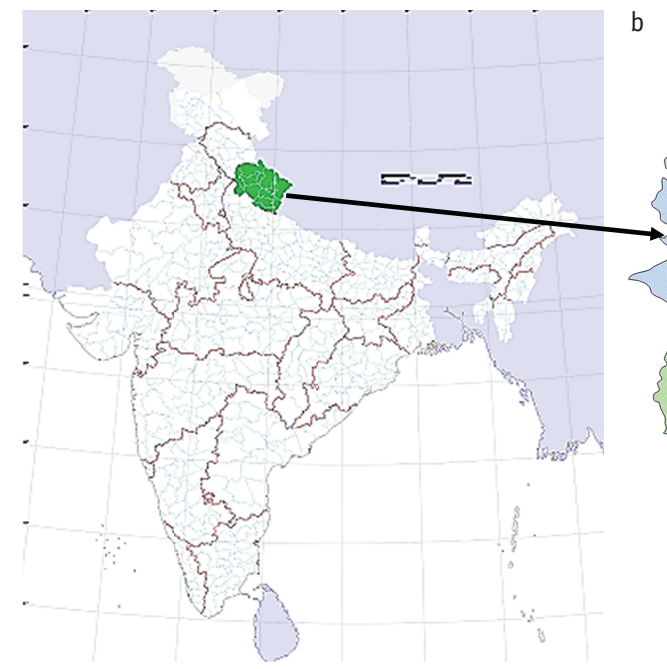

b

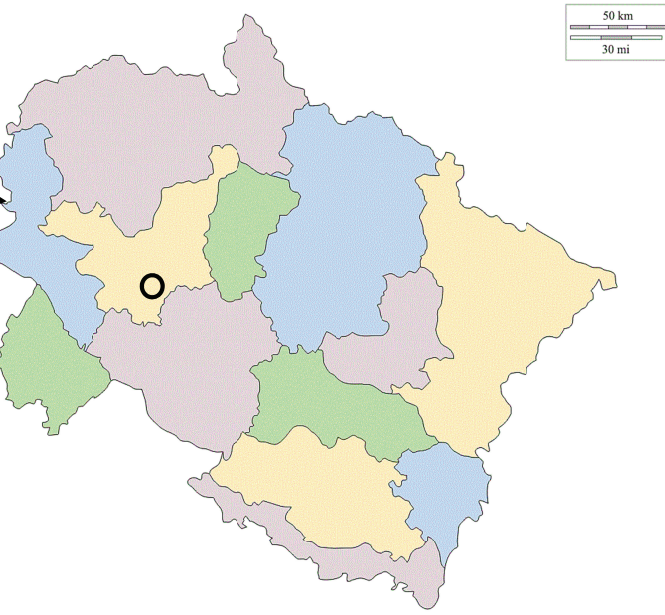

Figure 1. Map of study area. a - location of Uttarakhand State in India; b - map of Uttarakhand State; - location of study site.

oak forest some reasons that have been suggested to explain the poor regeneration are erratic seed production, defoliation, acorn herbivory, browsing damage to seedlings, forest fire, extensive lopping, accumulation of thick litter with slow decomposition rate, infestation by stem parasites such as mistletoe and leaf damage by insect pests. Grazing activity by large herbivores influences numerous processes associated with the recruitment of individual to a plant population (Hunt, 2001). These factors continuously interfere with the natural regeneration of oak forest (Shrestha, 2003). Seed size is perhaps the most important factor influencing recruitment success in tree species (Gross, 1984; Foster \& Janson, 1985; Turnbull et al., 1999; Dalling \& Hubbell, 2002).

\section{Material and Methods}

The study was conducted in Chandrabadani oak forest, a moist-temperate forest falling at the jurisdiction of Tehri district of Uttarakhand State, India. It lies at $30^{\circ} 08^{\prime}$ $17.4^{\prime \prime} \mathrm{N}$ latitude and $78^{\circ} 50^{\prime} 47.4^{\prime \prime} \mathrm{E}$ longitudes (Figure 1). A total of six transects were laid down along altitudinal gradient (03 each in north-facing and south-facing aspects). Sample plots (each $10 \times 10=100 \mathrm{~m}^{2}$ ) for tree inventory and nested plots (each $1 \times 1=$ $1 \mathrm{~m}^{2}$ ) in $100 \mathrm{~m}^{2}$ for seedling analysis were laid down. Transects were spatially distributed so as to minimize the autocorrelation among the vegetation. Quadrats were laid down along each transect in stratified random manner. The whole study area was divided into three altitudinal ranges: upper altitudinal range (> 1,900 $\mathrm{m}$ a.s.1.), middle altitudinal range $(1,700$ to $1,900 \mathrm{~m}$ a.s.l.) and lower altitudinal range $(<1,700 \mathrm{~m}$ a.s.l. $)$ in north and south facing aspects.

Degree of disturbance in studied area was measured in terms of percent of canopy cover $(\%)$, tree density $\left(\mathrm{h}^{-1}\right)$, lopping intensity $(\%)$ and number of cut stumps $\left(\mathrm{h}^{-1}\right)$. On the basis of these factors, an Index was set up with the help of minimum and maximum values of above mentioned disturbance parameters and then each altitudinal range at $100 \mathrm{~m}$ interval has been classified into following disturbance categories as (i) highly disturbed (ii) moderately disturbed and (iii) undisturbed (Table 1). 
Table 1. Disturbance categorization of Chandrabadni oak forest.

\begin{tabular}{lccc}
\hline $\begin{array}{l}\text { Disturbance } \\
\text { parameters }\end{array}$ & $\begin{array}{c}\text { Undis- } \\
\text { turbed }\end{array}$ & $\begin{array}{c}\text { Moderately } \\
\text { disturbed }\end{array}$ & $\begin{array}{c}\text { Highly } \\
\text { disturbed }\end{array}$ \\
\hline $\begin{array}{l}\text { Tree Density } \\
\left(\mathrm{h}^{-1}\right)\end{array}$ & $>1,200$ & $800-1,200$ & $<800$ \\
$\begin{array}{l}\text { Canopy cover } \\
(\%)\end{array}$ & $>50$ & $30-49$ & $<30$ \\
$\begin{array}{l}\text { Lopping (\%) } \\
\text { No. of cut }\end{array}$ & $<20$ & $21-29$ & $>30$ \\
$\begin{array}{l}\text { Ntumps }\left(\mathrm{h}^{-1}\right) \\
\text { st }\end{array}$ & $81-149$ & $>150$ \\
\hline
\end{tabular}

\section{Results}

Different disturbance classes of the studied area shown in Table 2. In whole study area, middle altitude of north aspect and upper altitude of south aspect was recorded under undisturbed stand. The moderately disturbed stands was observed in the upper and middle altitude of north and south aspect respectively, while the lower altitudes of both the north and south aspects was under highly disturbed stand.

Overall results showed that the girth class distribution among all disturbance stands varied with the disturbance intensity. The density of trees was found greater in middle girth classes as compared to higher girth classes. In the north aspect the highest (600 plants / ha) tree density was found in the undisturbed stand for $30-40 \mathrm{~cm}$ diameter at breast height (DBH) followed by 500 plants/ha in the moderately disturbed stand for 30-40 cm DBH class and 420 plants / ha in the undisturbed stand for 40$50 \mathrm{~cm}$ DBH class. While lowest (20 plants / ha) tree density was recorded at moderately disturbed stand in 80-90 cm DBH class. In the south aspect comparatively low tree density of banj oak Quercus leucotrichophora was found. Banj oak is the most common broadleaf tree in the mid-elevational ranges of central Himalaya in India. This broadleaved genus of family Fagaceae has many superior characteristics for its wide accep- tance as fuel, timber and nutritious fodder throughout the Himalaya (Saxena \& Singh, 1982). The maximum (420 plants / ha) tree density was recorded at moderately disturbed stand in 40-50 cm DBH class followed by 360 plants / ha for $50-60 \mathrm{~cm}$ DBH class in moderately disturbed stand and in undisturbed stand at $40-50 \mathrm{~cm}$ of DBH class (Figure 2). Among all disturbance stands the tree density of Q. leucotrichophora individuals was peaked at $40-50 \mathrm{~cm}$ and $50-$ $60 \mathrm{~cm}$ DBH classes and low tree density was observed for the Q. leucotrichophora density with the increasing DBH classes up to 50-60 $\mathrm{cm}$ DBH class. It may be due to cutting of mature trees (higher girth classes) by the local people for fuel wood in the study area (Figure 2).

The study revealed the highest seedling density in moderately disturbed stands followed by undisturbed and highly disturbed stand between both the aspects. However the tree stand density was highest at undisturbed stand followed by moderately and highly disturbed stand among all stands across the aspects (Figure 3). Poor seedling density was observed in the undisturbed stand at south facing aspect as compared to the moderately and highly disturbed stands. It may be due to long radiation period which cause low soil moisture and inhibited the seedling emergence or establishment. On the other hand, tree and seedling density of $Q$. leucotrichophora varied with the disturbance intensity and in different proportion. In the north facing aspect, the highest tree density (740 plants / ha) was observed at undisturbed stand followed by moderately disturbed stand (560 plants / ha) and highly disturbed stand (310 plants / ha) (Figure 3a). The seedling density was highest (1,060 plants / ha) at undisturbed stand followed by highly disturbed stand (1,000 plants / ha) and moderately disturbed stand (880 plants / ha) (Figure 3a). In the south aspect the higher tree density was recorded at undisturbed stand followed by moderately disturbed stand and highly disturbed stand. How- 
Table 2. Disturbance parameters observed in different disturbance gradients.

\begin{tabular}{lcccccc}
\hline & \multicolumn{2}{c}{ Undisturbed } & \multicolumn{2}{c}{ Moderately disturbed } & \multicolumn{2}{c}{ Highly disturbed } \\
\cline { 2 - 7 } Parameters & North middle & South upper & North upper & South middle & North lower & South lower \\
\cline { 2 - 7 } & $(1,781 \mathrm{~m})$ & $(2,103 \mathrm{~m})$ & $(2,092 \mathrm{~m})$ & $(1,829 \mathrm{~m})$ & $(1,597 \mathrm{~m})$ & $(1,563 \mathrm{~m})$ \\
\hline Density / ha & $1,330 \pm 20$ & $1,220 \pm 12$ & $1,060 \pm 16$ & $1,010 \pm 10$ & $780 \pm 8$ & $790 \pm 8$ \\
Canopy cover (\%) & 60.9 & 56.5 & 34.5 & 42.5 & 27.7 & 28.1 \\
Lopping (\%) & 15.5 & 18.3 & 27.7 & 24.6 & 38.9 & 39.4 \\
Cut stumps / ha & 50 & 50 & 130 & 110 & 210 & 180 \\
\hline
\end{tabular}
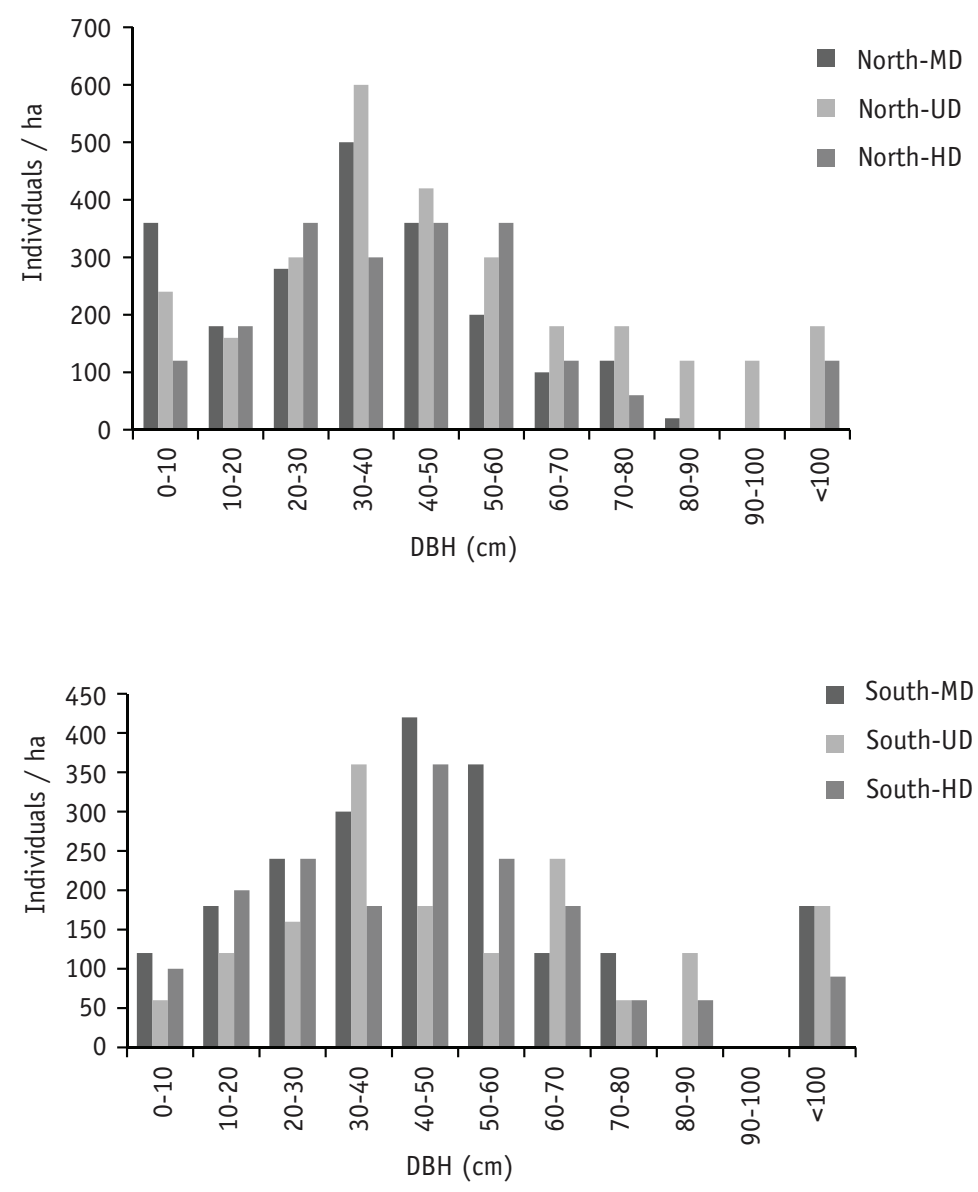

Figure 2. Density and diameter at breast height (DBH) of Quercus leucotrichophora among different disturbance gradients. North - north facing aspect, South - south facing aspect, UD - undisturbed, MD - moderately disturbed, HD - highly disturbed. 
ever, the seedling density was highest (780 plants / ha) at undisturbed and highly disturbed stand and lowest (760 plants / ha) at moderately disturbed stand (Figure 3a).

The tree density of $Q$. leucotrichophora was higher in the undisturbed stand followed by moderately disturbed and highly disturbed stand (Figure 3b). But in case of seedling density the higher density were observed at undisturbed and highly disturbed stand in both the aspects. It may be due to removal of litter and herbaceous biomass in the highly disturbed stands which create suitable microenvironment for seedling growth and development.

\section{Discussion}

In present investigation the highest stand density $\left(1,330\right.$ tree ha- $\left.{ }^{-1}\right)$ and $\left(1,220\right.$ tree ha $\left.{ }^{-1}\right)$ was recorded in the undisturbed stand at north middle altitude and south upper altitude respectively. The canopy cover ranged from $27.7 \%$ at highly disturbed stand to $60.9 \%$ at undisturbed stand. Uniyal et al. (2010) recorded that the undisturbed forest stand had canopy cover $>60 \%$, cut stump index $<2$ and 2,144 trees ha ${ }^{-1}$, whereas the highly disturbed stand had canopy cover $<49 \%$, cut stump index $>7$ and 804 trees $\mathrm{ha}^{-1}$ in $Q$. leucotrichophora forest. The diameter distribution of trees has often been used to represent the population structure of forests (Saxena et al., 1984; Khan et al., 1987). A bell shaped structure was formed by density-diameter curve under different diameter classes of Q. leucotrichophora is found similar to Sagar \& Singh (2005), who reported concave appearance for the density - diameter curve of the dry deciduous forest of North-East India. Vetaas (2000) indicated that the size class distributions indicate different population structures, which may be related to differences in environment and disturbance regimes of brown oak $Q$. semecarpifolia Sm. in Central Himalaya. The population structure of $Q$. semecarpifolia in the almost undisturbed stand which tend to a continuous regeneration. Although a clear bell shaped size-class distribution is absent in disturbed forest. This effect of disturbance has been shown in similar evergreen oak forests in Himalaya (Saxena et al., 1984; Rao et al., 1990).

Parthasarthy (2001) studied the changes in forest composition and structure in undisturbed (UD), selected-felled (SF) and moderately disturbed (MD) stands in tropical evergreen forest of Western Ghats and indicated that higher individual density under the $30-60 \mathrm{~cm}$ of girth class in all three stands and a continuous downfall as the girth class increased from $60-90 \mathrm{~cm}$ to $>210 \mathrm{~cm}$ of girth class. Our findings were found similar to Sagar \& Singh (2005), who reported concave appearance for the $\mathrm{d}$-d curve (dominance-density curves based on the dominance and density of tree species) of the dry deciduous forest of North-East India.

The seedling density was recorded lower in undisturbed stand at south facing aspect as compared to the moderately and highly disturbed stands. It may be due to high radiation in south aspect, which cause low soil moisture and inhibited the seedling emergence or establishment. Sagar \& Singh (2005) reported highest seedling density at low disturbed site followed by high disturbed and moderately disturbed sites. They also concluded that the seedling and adult distributions were not spatially associated and seedling community on a site was distinct from the adult tree community.

\section{Conclusions}

The study points out an urgent need for the conservation of $Q$. leucotrichophora forest, thus stronger protection and regulatory measures are required. Unmanaged extraction of trees, collection of fuel-wood and fodder by the villagers and over grazing by domestic animals were the major factors of disturbance in the study area. The regeneration of $Q$. leucotrichophora was found severe- 

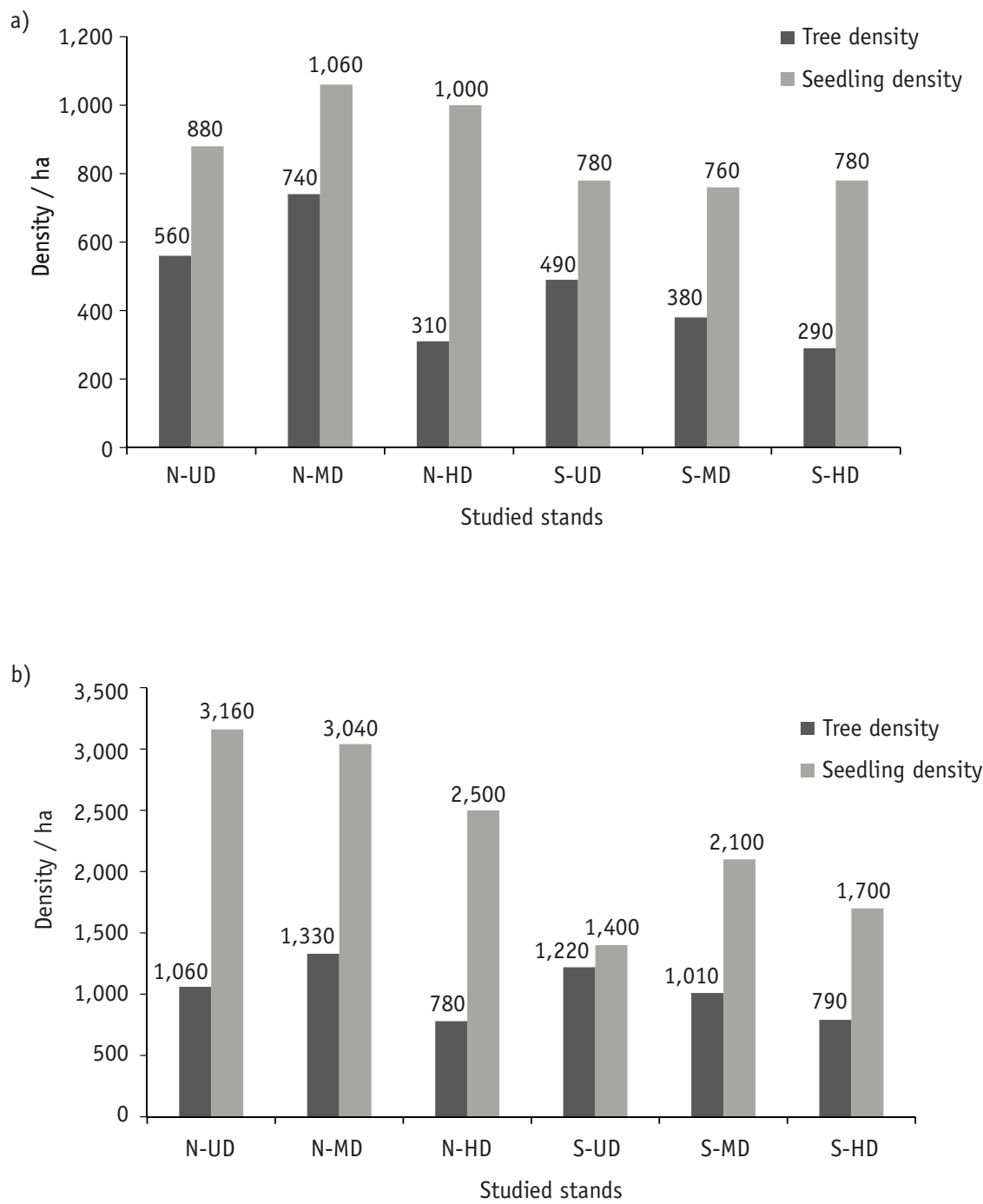

Figure 3. (a) Stand tree and seedling density; (b) Quercus tree and seedling density along anthropogenic disturbance gradients. $\mathrm{N}$ - north facing aspect, $\mathrm{S}$ - south facing aspect, UD - undisturbed, MD moderately disturbed, HD - highly disturbed.

ly influenced by insect attack on the fallen seeds, seed predation by birds, overcrowding of herbaceous layer and excess litter fall. The disturbance led to thinning of woody layer and change in the microenvironment which, in turn might have impaired regeneration process of the species on one hand, and colonization and establishment of shade-tolerant shrubs and annuals on the other hand. These factors should be taken into account, while formulating strategies for conservation and management of these forests.

Acknowledgements. Authors are thankful to MoEFCC New Delhi, India for the financial assistance for $\mathrm{R} \& \mathrm{D}$ project. 


\section{References}

Coates, K.D. 2002. Tree recruitment in gaps of various size, clearcuts and undisturbed mixed forest of interior British Columbia, Canada. Forest Ecology and Management, 155, 387-398.

Dalling, J.W., Hubbell, S.P. 2002. Seed size, growth rate and gap microsite conditions as determinants of recruitment success for pioneer species. - Journal of Ecology, 90, 557-568.

Foster, S.A., Janson, C.H. 1985. The relationship between seed size and establishment conditions in tropical woody plants. - Ecology, 66, 773-780.

Gross, K.L. 1984. Effects of seed size and growth form on seedling establishment of six monocarpic perennial plants. - Journal of Ecology, 72, 369-387.

Hunt, L.P. 2001. Low seed availability may limit recruitment in grazed Atriplex vesicaria and contribute to its local extinction. - Plant Ecology, 157, 53-67.

Khan, M.L., Rai, J.P.N., Tripathi, R.S. 1987. Population structure of some tree species in disturbed and protected sub-tropical forests of northeast India. - Acta Ecology, 8, 247-255.

Krauchi, N., Brang, P., Schonenberger, W. 2000. Forests of mountainous regions: Gaps in knowledge and research needs. - Forest Ecology and Management, 132, 73-82.

Mori, A., Takeda, H. 2004. Effect of undisturbed canopy structure on population structure and species coexistence in an old growth sublpine forest in Central Japan. - Forest Ecology and Management, 200, 89-100.

Oliver, C.D., Larson, B.C. 1990. Forest stand dynamics. McGraw-Hill,Inc., New York, 467 pp.

Parthasarthy, N. 2001. Changes in forest composition and structure in three sites of tropical evergreen forests around Sengltheri, Western Ghats. - Current Science, 80, 389-393.

Rao, P., Barik, S.K., Pandey, H.N., Tripathi, R.S. 1990. Community composition and tree population structure in a sub-tropical broad-leaved forest along a disturbance gradient. - Vegetatio, $88,151-162$.

Sagar, R., Singh, J.S. 2005. Structure, diversity and regeneration of tropical deciduous forest of northern India. - Biodiversity and Conservation, 14, 935-959.

Saxena, A.K., Singh. J.S. 1982. A phytosociological analysis of woody species in forest communities of a part of Kumaun Himalaya. - Vegetatio, $50,3-22$.

Saxena, A.K., Singh. S.P., Singh. J.S. 1984. Population structure of forests of Kumaon Himalaya: Implications for management. - Journal of Environmental Management, 19, 307-324.

Shrestha, B.B. 2003. Quercus semecarpifolia Sm. in the Himalayan region: Ecology, exploitation and threats. - Himalayan Journal of Sciences, 1(2), 126-128.

Stone, J.N., Porter, J.L. 1998. What is stand structure and how to measure it? - Northwest Science, 72(2), 25-26.

Turnbull, L.A., Rees, M., Crawley, M.J. 1999. Seed mass and the competition/colonization tradeoff: a sowing experiment. - Journal of Ecology, 87, 899-912.

Vetaas, O.R. 2000. Does regulated land use allow regeneration of keystone forest species in the Annapurna conservation area, Central Himalaya? Mountain Research and Development, 27(4), 345-351.

Winn, A.A., Werener, P.A. 1987. Regulation of seed yield within and among populations of Prunella vulgaris. - Ecology, 68, 1224-1233. 